\title{
Negatywna integracja uregulowań prawa krajowego państw czlonkowskich UE w zakresie korekty zysków przedsiębiorstw powiązanych
}

Konwencja Arbitrażowa w sprawie eliminowania podwójnego opodatkowania w przypadku korekty zysków przedsiębiorstw powiązanych jako wielostronna umowa międzynarodowa, podobnie jak traktaty założycielskie UE, nie podlega kognicji TS UE. Niemniej uregulowania prawa podatkowego państw członkowskich UE, odwołujące się do zasady długości ramienia, do pewnego tylko stopnia stały się przedmiotem oceny TS UE w kontekście ich zgodności z gwarantowanymi przez TFUE fundamentalnymi swobodami traktatowymi ${ }^{1}$. Wśród orzeczeń TS UE mających znaczenie dla analizowanej problematyki wymienić należy w pierwszej kolejności wyrok TS UE z dnia 12 grudnia 2002 r. w sprawie C-324/00 Lankhorst-Hohorst GmbH [ECR I-11779] ${ }^{2}$, wyrok TS UE z dnia 17 marca 2007 r. w sprawie C-524/04 Test Claimants in the Thin Cap Group Litigation $^{3}$, wyrok TS UE z dnia 17 stycznia 2008 r. w sprawie C-105/07, NV Lammers \& Van Cleeff przeciwko Królestwu Belgii ${ }^{4}$ oraz wyrok TS UE z dnia 21 stycznia 2010 r. w sprawie C-311/08 Societé de Gestion Industrelle SA (SGI) przeciwko Królestwu Belgii ${ }^{5}$. Badając zgodność prawa krajowego w zakresie cen transferowych i podmiotów powiązanych, TS UE wychodzi z założenia, że poza obszarami objętymi postanowieniami norm prawa wtórnego UE stanowienie przepisów prawa podatkowego w odniesieniu do podatków bezpośrednich należy do wyłącznej kompetencji każdego państwa członkowskiego, jednakże państwo członkowskie, wykonując swoje władztwo podatkowe w tym zakresie, zobowiązane jest wykonywać je w zgodzie z prawem unijnym ${ }^{6}$.

* Dr Ziemowit Kukulski - Katedra Materialnego Prawa Podatkowego, Wydział Prawa i Administracji, Uniwersytet Łódzki.

${ }^{1}$ Por. B. J. M. Terra, P. J. Wattel, European Tax Law, $5^{\text {th }}$ edition, Deventer 2008, s. 287-290.

2 Zob. ECJ Direct Tax Compass 2011, IBFD, Amsterdam 2011, s. 169-172.

3 Tamże, s. 176-180.

4 Tamże, s. 186-188.

5 Tamże, s. 199-201.

${ }^{6}$ Por. C-410/98 Metallgesellschaft and Others, pkt 37; C-446/03 Marks \& Spencer, pkt 29; C-374/04 Test Claimants in Class IV of the ACT Group Litigation, pkt 36; por. ECJ Direct Tax Compass 2011, s. 104-107, 120, 125. 
Wyrok TS UE w sprawie C-324/00 Lankhorst-Hohorst GmbH dotyczył oceny zgodności niemieckich przepisów w zakresie niedostatecznej kapitalizacji z gwarantowaną przez prawo pierwotne UE swobodą przedsiębiorczości (art. 43 TWE, obecnie art. 49 TFUE). Niedostateczna kapitalizacja polega na nadmiernym finansowaniu spółek kapitałowych przez jej znaczących udziałowców (akcjonariuszy), udziałowców (spółki dominujące) za pomocą dłużnych instrumentów finansowania (pożyczka), noszących znamiona ukrytego wkładu do kapitału zakładowego spółki zależnej. Nadużywanie dłużnych instrumentów finansowania w celu dokapitalizowywania podmiotów zależnych może, choć nie w każdym przypadku, prowadzić do naruszenia zasady długości ramienia. Dzieje się tak nie tylko wówczas, gdy wysokość oprocentowania pożyczki rażąco odbiega od oprocentowania stosowanego $\mathrm{w}$ transakcjach zawieranych przez podmioty niepowiązane, ale także wtedy gdy inne warunki umowy - takie jak np. wysokość pożyczonej kwoty, terminy i warunki spłaty pożyczki - noszą de facto znamiona ukrytego wkładu do kapitału zakładowego spółki dłużnika (tzw. hybrydowe instrumenty finansowania).

Wskazanym wyżej zjawiskom, podobnie jak przerzucaniu dochodów generowanych w wyniku transakcji zawieranych przez podmioty powiązane, towarzyszy erozja podstawy opodatkowania spółki - dłużnika, negatywnie oceniana z pozycji interesów fiskalnych państw członkowskich UE. Jednakże minimalizacja lub nawet całkowita redukcja wysokości obciążeń podatkowych nie może stanowić samoistnej podstawy do uznania, iż ochrona interesu publicznego oraz zapewnienie spójności systemowi podatkowemu czy konieczność zapewnienia efektywności nadzoru podatkowego wymaga zastosowania mniej korzystnego reżimu opodatkowania takiej transakcji w porównaniu z transakcjami, w których uczestniczą wyłącznie rezydenci tego samego państwa członkowskiego ${ }^{7}$. Uregulowania prawa wewnętrznego, różnicujące sytuację prawnopodatkową podatników w oparciu o wskazaną wyżej przesłankę, stanowią naruszenie swobody przedsiębiorczości i powinny być uchylone jako niezgodne z prawem UE. Powyższe tezy znajdują swoje odzwierciedlenie w pełni wyroku TS UE w sprawie Lankhorst-Hohorst $\mathrm{GmbH}$.

Niemieckie przepisy w zakresie niedostatecznej kapitalizacji, będące przedmiotem oceny TS UE w wyroku w sprawie C-324/00 Lankhorst-Hohorst GmbH, modyfikowały istotnie zasady opodatkowania odsetek wypłacanych przez spółkę zależną w związku z pożyczką udzieloną tej spółce przez udziałowca (akcjonariusza) mającego status znaczącego udziałowca. Oparte były i są na metodzie wskaźnika wartości zadłużenia spółki do wartości jej kapitału zakładowego - 3 : 1 (w owym czasie), który ustalał dopuszczalne proporcje, w jakich kapitał dostar-

${ }^{7}$ Por. wyroki TS UE w sprawach: C-264/96 ICI [1998] ECR I-4695, pkt 28; C-35/98 Verkooijen, pkt 59; Metallgesellschaft and Others, pkt 59 oraz C-307/97 Saint-Gobain ZN [1999] ECR I-6161, pkt 51 . 
czony spółce przez udziałowców (akcjonariuszy) w formie pożyczek powinien pozostawać w stosunku do kapitału zakładowego ${ }^{8}$. Oznaczało to, że jeżeli wartość zadłużenia spółki rezydenta Niemiec wobec udziałowców (akcjonariuszy) posiadających znaczący udział w jej kapitale przekroczyła trzykrotnie wartość jej kapitału zakładowego, odsetki wypłacone w związku z taką pożyczką nie stanowiły kosztów uzyskania przychodów dla spółki zależnej i traktowane były w celu ich opodatkowania tak jak dywidendy. Uregulowania te jedynie pośrednio odnosiły się do zasady długości ramienia, będącej normą wyceny transferu między podmiotami powiązanymi. Co do zasady reklasyfikacja odsetek $\mathrm{w}$ dywidendę dla celów opodatkowania nie następowała, jeżeli podatnik udowodnił, że możliwe było zaciągnięcie pożyczki przez spółkę zależną na takich samych warunkach, jak umowa zawarta ze znaczącym udziałowcem, z osobą trzecią - podmiotem niepowiązanym. W stanie faktycznym sprawy C-324/00 Lankhorst-Hohorst GmbH obok umowy pożyczki zawartej między niemiecką spółką zależną (dłużnikiem) a holenderską spółką dominującą (pożyczkodawcą) doszło do zawarcia dodatkowego porozumienia (niem. Patronetserklärung), zgodnie z którym holenderska spółka dominująca zrzekała się należnych jej odsetek w przypadku wystąpienia przez wierzycieli - osoby trzecie - z jakimikolwiek roszczeniami wobec niemieckiej spółki zależnej Lankhorst-Hohorst GmbH. Warunki Patronetserklärung dały niemieckim władzom podatkowym asumpt do twierdzenia, iż po pierwsze, pożyczka udzielona niemieckiej spółce zależnej Lankhorst-Hohorst GmbH jest de facto ukrytym wkładem do kapitału zakładowego, a po drugie, została zawarta wyłącznie w celu redukcji wysokości obciążeń podatkowych w państwie ich źródła. Zatem w ocenie niemieckich władz podatkowych transakcja zawarta pomiędzy niemiecką spółką zależną - dłużnikiem a holenderską spółką dominującą - pożyczkodawcą odbiegała od warunków wolnorynkowych w celu redukcji wysokości obciążenia podatkowego na poziomie niemieckiej spółki-dłużnika.

TS UE nie podzielił stanowiska niemieckich władz podatkowych, uznając niemieckie przepisy w zakresie niedostatecznej kapitalizacji za niezgodne ze swobodą przedsiębiorczości (art. 43 TWE, obecny art. 49 TFUE). Podstawą rozstrzygnięcia TS UE był fakt, iż restrykcje dotyczące finansowania spółek zależnych długiem znajdowały zastosowanie wyłącznie do pożyczek udzielonych niemieckiej spółce zależnej przez udziałowców (akcjonariuszy) - nierezydentów oraz rezydentów Niemiec, którzy byli zwolnieni w Niemczech z podatku dochodowego od osób prawnych (wąska grupa podmiotów - podmioty prawa publicznego). Przewidziana przez prawo niemieckie zmiana kwalifikacji prawnej odsetek w dywidendę dla celów ich opodatkowania (reklasyfikacja) dotyczyła de facto odsetek od pożyczek udzielonych przez zagranicznych udziałowców

${ }^{8}$ Z. Kukulski, Niedostateczna kapitalizacja $w$ prawie podatkowym, Warszawa 2006, s. 87 i n.; R. A. Sommerhalder, International Approaches to Thin Capitalization, „European Taxation” 1996, no. 3, s. 82; por. R. Stricof, K. Nakhai, Thin Capitalization Rules and Non-Discrimination Principles, „Intertax” 2004, no. 3, s. 126-137. 
(akcjonariuszy) niemieckiej spółce zależnej. Jednocześnie w wyroku w sprawie C-324/00 Lankhorst-Hohorst TS UE uznał, że normy ograniczające niedostateczną kapitalizację - takie jak obowiązujące w Niemczech - nie mogą mieć wyłącznie na celu ograniczenia możliwości finansowania za pomocą długu krajowych spółek zależnych przez spółki dominujące nierezydentów. Ratio legis owych przepisów winna być przede wszystkim ochrona interesu publicznego rozumianego jako zapobieganie ujemnym skutkom erozji podstawy opodatkowania spółek zależnych finansowanych nadmiernie przez zagranicznych udziałowców, posiadających znaczący udział w ich kapitale za pomocą zwrotnych instrumentów finansowania (pożyczki) w celu uniknięcia opodatkowania dochodów z tytułu odsetek w państwie ich źródła. Takie transakcje, o ile nie stoi za nimi realne i obiektywne z ekonomicznego punktu widzenia uzasadnienie, mogą być uznane za sztuczne i zaaranżowane przez podatników wyłącznie w celu minimalizacji lub całkowitej redukcji podatku u źródła.

Oznacza to, że w kontekście gwarantowanych przez prawo unijne fundamentalnych swobód traktatowych, normy służące ograniczaniu niedostatecznej kapitalizacji oraz normy dopuszczające korektę dochodów (zysków) podmiotów powiązanych mogą różnicować sytuację prawnopodatkową rezydentów w porównaniu z sytuacją podatkową nierezydentów uczestniczących w zawieranej transakcji, o ile jest to usprawiedliwione koniecznością zapobiegania unikaniu opodatkowania lub uchylaniu się od opodatkowania. Oceniając przesłanki pozwalające stwierdzić, czy dana transakcja zawarta przez podmioty powiązane ma wyłącznie na celu uniknięcie opodatkowania lub uchylanie się od opodatkowania, TS UE odwołał się do koncepcji zasady długości ramienia (tzw. arm's lenght test $)^{9}$. Transakcja kontrolowana między podmiotami powiązanymi, rezydentami dwóch różnych państw członkowskich UE, może być poddana w państwie członkowskim mniej korzystnemu reżimowi opodatkowania, w porównaniu z tym, jaki ma zastosowanie do transakcji kontrolowanych zawieranych między podmiotami powiązanymi rezydentami tego samego państwa członkowskiego, pod warunkiem, że z całokształtów uzgodnionych warunków i okoliczności, w jakich doszło do jej zawarcia, wynika, że transakcja ta ma w całości sztuczny charakter i została dokonana wyłącznie w celu „obejścia” wewnętrznych przepisów podatkowych danego państwa członkowskiego. Niemieckie przepisy w zakresie niedostatecznej kapitalizacji nie spełniały w ocenie TS UE powyższego warunku, mimo iż ich konstrukcja w pewnym zakresie opierała się na zasadzie długości ramienia. Podstawą prawną zastosowania mniej korzystnego reżimu opodatkowania odsetek wypłaconych nierezydentowi był bowiem w tym przypadku nie fakt narzucenia lub uzgodnienia $\mathrm{w}$ umowie pożyczki warunków odbiegających od tych, jakie uzgodniłyby między sobą niezależne podmioty, ale fakt przekroczenia przez zadłużenie niemieckiej spółki, w proporcji do wartości jej kapitału zakładowego, ustawowo określonego wskaźnika.

${ }^{9}$ B. J. M. Terra, P. J. Wattel, op. cit., s. 287. 
Teza wyroku w sprawie C-324/00 Lankhorst-Hohorst GmbH została następnie powtórzona i rozwinięta przez TS UE w dwóch kolejnych orzeczeniach dotyczących niedostatecznej kapitalizacji: w sprawie C-524/04 Test Claimants in the Thin Cap Group Litigation oraz C-105/07 NV Lammers \& Van Cleef vs. Belgische Staat, w których TS UE potwierdził swoją akceptację dla zasady długości ramienia jako międzynarodowej normy pozwalającej w przypadkach niedostatecznej kapitalizacji na dokonanie reklasyfikacji odsetek wypłacanych przez spółkę zależną spółce dominującej w związku z pożyczką udzieloną przez spółkę dominującą w dywidendę dla celów opodatkowania. Ponadto, TS UE rozwinął w nich koncepcję usprawiedliwionego ograniczenia rezydentom innego państwa członkowskiego UE gwarantowanych przez prawo pierwotne UE fundamentalnych swobód traktatowych w oparciu o potrzebę zapobiegania przez państwo członkowskie UE unikaniu opodatkowania oraz uchylaniu się od opodatkowania ${ }^{10}$. Jednak także i w tym przypadku ograniczenie swobody przedsiębiorczości przez przepisy prawa wewnętrznego państwa członkowskiego nie mogą wykraczać poza zakres tego, co jest niezbędne dla realizacji ww. celu.

Sprawa C-524/04 Test Claimants in the Thin Cap Group Litigation dotyczyła zgodności obowiązujących w Wielkiej Brytanii przepisów ograniczających niedostateczną kapitalizację z gwarantowanymi przez TWE (obecnie TFUE) fundamentalnymi swobodami traktatowymi. Brytyjskie przepisy ograniczające niedostateczną kapitalizację wprost odwoływały się do zasady długości ramienia, na której opierają się przepisy prawa wewnętrznego dopuszczające korektę zysków wynikających z transakcji pomiędzy podmiotami powiązanymi ${ }^{11}$. Ograniczenie finansowania podmiotów powiązanych za pomocą długu polegało na reklasyfikacji odsetek od pożyczki w dywidendę dla celów opodatkowania, w przypad$\mathrm{ku}$, gdy strony ustaliły w umowie oprocentowanie w wysokości przekraczającej racjonalną z gospodarczego punktu widzenia stopę oprocentowania stosowaną $\mathrm{w}$ obrocie pomiędzy podmiotami niepowiązanymi (ang. excessive interest rate). $\mathrm{Z}$ omawianych przepisów wynikały de facto dwa różne reżimy opodatkowania nadmiernych odsetek, gdyż zmiany, jakie nastąpiły w latach 1995-2004, zawęziły przedmiotowy zakres omawianych regulacji wyłącznie do transgranicznej wypłaty odsetek. W konsekwencji ujemne konsekwencje wynikające z zastosowania owych przepisów dotykały wyłącznie spółek zależnych - rezydentów Wielkiej Brytanii, które zadłużały się u zagranicznych, w tym unijnych, spółek powiązanych, zaś sam fakt uzgodnienia w umowie między spółką zależną rezydentem Wielkiej Brytanii i zagraniczną spółką powiązaną oprocentowania wyższego

${ }^{10}$ Zob. S. van Thiel, Justifications in Community Law for Income Tax Restrictions on Free Movement: Acte Clair Rules That Can Be Readily Applied by National Courts - Part 1, „European Taxation" 2008, no. 6, s. 279 i n.; por. I. Angelova, Justifications for Restricting Fundamental Freedoms Accepted by the European Court of Justice, „The EC Tax Journal” 2011-2012, vol. 12, s. 99-116.

${ }^{11}$ A. K. Rowland, Thin Capitalization in U.K., „Bulletin of International Bureau of Fiscal Documentation" 1995 , no. 12, s. 554-555. 
od stosowanego w transakcjach pomiędzy podmiotami niepowiązanymi równoznaczny był z uzyskaniem korzyści podatkowych polegających na redukcji wysokości obciążeń podatkowych spółki zależnej w Wielkiej Brytanii.

W wyroku w sprawie C-524/04 Test Claimants in Thin Cap Group Litigation TS UE sformułowano dwie przesłanki, w oparciu o które należy badać zgodność wewnętrznych przepisów ograniczających niedostateczną kapitalizację, odwołujących się do zasady długości ramienia w kontekście usprawiedliwionego ograniczenia swobody przedsiębiorczości. Mogą one stanowić usprawiedliwione ograniczenie swobody przedsiębiorczości, jeżeli:

- znajdują zastosowanie wyłącznie do sztucznych w całości transakcji, dokonanych w okolicznościach bezspornie wskazujących na zamiar minimalizacji lub całkowitej redukcji obciążeń podatkowych w państwie źródła i jednocześnie podatnik nie może przedstawić dowodów uzasadniających z ekonomicznego punktu widzenia celowość zawarcia transakcji na warunkach różniących się od warunków rynkowych;

- w przypadku spełnienia pierwszej przesłanki, skutki wynikające z zastosowania przepisów ograniczających niedostateczną kapitalizację (w tym przypadku reklasyfikacja) nie mogą obejmować całej kwoty odsetek, ale ich część, która przekracza stopę procentową, jaką w porównywalnych warunkach ustaliłyby podmioty niepowiązane.

W praktyce oznacza to, że przepisy ograniczające niedostateczną kapitalizację mogą zmierzać do eliminacji negatywnych skutków unikania przez podatników opodatkowania i tym samym dopuszczać w pewnych sytuacjach reklasyfikację odsetek, pod warunkiem i tylko w takim zakresie, w jakim wysokość odsetek uzgodniona między spółkami powiązanymi odbiega od wysokości oprocentowania, jaką uzgodniłyby między sobą niezależne podmioty. Jeżeli warunki, na jakich dochodzi do zawarcia umowy pożyczki między spółką zależną rezydentem jednego państwa członkowskiego a spółką dominującą innego państwa członkowskiego, nie różnią się od warunków rynkowych, wtedy nie ma podstaw do odmiennego traktowania pod względem podatkowym wypłaconych $\mathrm{w}$ związku z taką umową odsetek. TS UE uznał jednocześnie, że do wyłącznej kompetencji sądów krajowych należy ustalenie, czy dana transakcja spełnia warunki zgodności z zasadą długości ramienia oraz czy w każdym przypadku przepisy prawa podatkowego obowiązujące w państwie członkowskim stwarzają podatnikowi możliwość przedstawienia dowodów uzasadniających odejście w konkretnej transakcji od zasady długości ramienia.

Podobne tezy sformułowano w wyroku z dnia 17 stycznia 2008 r. w sprawie C-105/07, NV Lammers \& Van Cleeff vs. Belgische Staat, dotyczącym belgijskich przepisów w zakresie niedostatecznej kapitalizacji. Stanowi on jednak uzupełnienie dotychczasowej linii orzeczniczej TS, w szczególności w odniesieniu do wyroku w sprawie C-524/04 Test Claimants in the Thin Cap Group Litigation. TS rozwinął $\mathrm{w}$ nim tezę usprawiedliwionego ograniczenia swobody przedsiębiorczości w kontekście przepisów ograniczających niedostateczną kapitalizację 
poprzez doprecyzowanie koncepcji ,sztuczności” transakcji zawartej wyłącznie w celu minimalizacji lub całkowitej redukcji obciążeń podatkowych w państwie źródła odsetek, wskazując na znaczenie zasady długości ramienia jako kryterium pozwalającego na ocenę rzeczywistego zamiaru stron zawierających umowę pożyczki. Oceniając przepisy prawa krajowego odwołujące się do zasady długości ramienia, TS UE kładzie nacisk na respektowanie przez prawodawcę krajowego zasady proporcjonalności $\mathrm{w}$ aspekcie usprawiedliwionego ograniczenia swobody przedsiębiorczości. Zasada ta ma być dla ustawodawcy krajowego wskazówką, że wprowadzając restrykcyjne względem swobód traktatowych uregulowania prawa wewnętrznego, musi zachować równowagę między celem takich regulacji (eliminacją unikania opodatkowania) a skutkami, jakie mogą wyniknąc ze stosowania owych ograniczeń (ograniczeniem swobody przedsiębiorczości rezydentom innego państwa członkowskiego UE).

W orzeczeniu w sprawie C-105/07, NV Lammers \& Van Cleeff vs. Belgische Staat, TS UE uznał belgijskie przepisy ograniczające niedostateczną kapitalizację za stanowiące nieusprawiedliwione ograniczenie traktatowej swobody przedsiębiorczości, o której mowa w art. 43 TWE (obecnie art. 49 TFUE) oraz art. 48 TWE (obecnie art. 54). Obowiązujące prawo wewnętrzne w Belgii, podobnie jak brytyjskie czy niemieckie, przewidywało reklasyfikację - tj. zmianę kwalifikacji prawnej odsetek od pożyczki udzielonej spółce przez pewną kategorię udziałowców (akcjonariuszy) w dywidendę, uniemożliwiając tym samym ich odliczenie od przychodu spółki dłużnika jako kosztu' ${ }^{12}$. Reklasyfikacja następowała, jeżeli wysokość odsetek od pożyczki udzielonej belgijskiej spółce przez członka jej zarządu nierezydenta przekraczała wysokość oprocentowania ustalaną w porównywalnych transakcjach między podmiotami niepowiązanymi (ang. excessive interest rate) lub jak miało to miejsce w przypadku NV Lammers \& Van Cleef, kwota pożyczki udzielonej przez członka zarządu - nierezydenta - przekraczała łącznie wartość opłaconego kapitału zakładowego spółki dłużnika i wartość opodatkowanych rezerw ustaloną na początku roku podatkowego w stosunku $1: 1$.

Odwołując się do orzeczeń w sprawach C-324/00 Lankhorst-Hohorst oraz C-524/04 Test Claimants in The Thin Cap Group Litigation, TS UE podkreślił, że przepisy w zakresie niedostatecznej kapitalizacji mogą pod pewnymi warunkami wprowadzać mniej korzystny dla nierezydentów reżim opodatkowania, o ile podstawowym celem takich regulacji jest zapobieganie unikaniu opodatkowania. Cel ten jest realizowany, jeżeli dochodzi do zawarcia umowy pomiędzy podmiotami powiązanymi, która ma w całości sztuczny charakter i nie można jej usprawiedliwić z ekonomicznego punktu widzenia. Oznacza to w praktyce, że jedynym celem takiej transakcji jest uniknięcie (np. zminimalizowanie lub całkowite wyeliminowanie) obowiązku podatkowego, jaki wynika z norm prawa podatkowego w państwie siedziby spółki zależnej. Zatem w pierwszej kolejności winno się

${ }_{12}$ Zob. Z. Kukulski, op. cit., s. 115-119; D. Plitz, International Aspects of Thin Capitalization Survey, „International Tax Review” 1994, no. 7/9, s. 24-25. 
ocenić, na ile i z jakich powodów warunki umowy pożyczki zawartej przez spółkę zależną z członkiem zarządu - spółką dominującą odbiegają od warunków, na jakich doszłoby do udzielenia pożyczki przez podmioty niepowiązane. Po drugie, należy zbadać, czy istnieją gospodarczo uzasadnione przyczyny, dla których podmioty powiązane zawarły umowę na warunkach odbiegających od warunków wolnorynkowych i wreszcie po trzecie - ocenić, czy wyłącznym zamiarem stron umowy nie było uzyskanie korzyści podatkowych, polegających na redukcji wysokości podatku dochodowego na poziomie spółki zależnej poprzez odliczenie od przychodu odsetek od pożyczki udzielonej przez członka zarządu. W ocenie TS UE dokonanie transakcji między podmiotami powiązanymi na warunkach odbiegających od warunków, jakie uzgodniłyby między sobą niezależne podmioty, działające w oparciu o zasadę długości ramienia, stanowi dla państwa członkowskiego - przy stosowaniu restrykcji - obiektywną przesłankę pozwalającą ocenić rzeczywisty zamiar (cel) stron, mianowicie, czy było nim udzielenie pożyczki, czy też wola zastąpienia kapitału zakładowego kapitałem dłużnym w celu minimalizacji lub całkowitej redukcji wysokości obciążeń podatkowych w państwie źródła odsetek. Niedopuszczalne jest stosowanie restrykcji ograniczających niedostateczną kapitalizację wyłącznie na podstawie samego faktu udzielenia pożyczki przez spółkę powiązaną spółce zależnej. Okoliczność ta nie może stanowić wyłącznej, samoistnej przesłanki uzasadniającej twierdzenie, że dana konkretna transakcja zmierza jedynie do uniknięcia opodatkowania ${ }^{13}$.

Belgijskie normy w zakresie niedostatecznej kapitalizacji, podobnie jak analogiczne uregulowania prawa niemieckiego czy brytyjskiego, wychodziły, zdaniem TS UE, znacznie poza założone przez prawodawcę ratio legis, bowiem dopuszczały one reklasyfikację odsetek od pożyczki udzielonej spółce zależnej przez członka zarządu - spółkę dominującą nierezydenta w każdej sytuacji, nawet jeżeli warunki uzgodnione przez strony w umowie (wysokość oprocentowania) nie odbiegały od tych, jakie uzgodniłyby między sobą niezależne podmioty ${ }^{14}$. W ocenie sędziów TS, z analizy stanu faktycznego wynikało, że reklasyfikacja odsetek w celu ich opodatkowania w dywidendę w okolicznościach nastąpiła na podstawie przekroczenia wskaźnika 1 do 1 wartości zadłużenia do wartości kapitału zakładowego, niezależnie od tego, czy transakcja, z tytułu której dokonano wypłaty odsetek, została zawarta na warunkach odpowiadających zasadzie długości ramienia. Z tego względu belgijskie przepisy w zakresie niedostatecznej kapitalizacji wychodzą poza zakres ratio legis w celu zwalczania nadużyciowych praktyk, adresowane są także do sytuacji, w których nie można dowieść nadużycia prawa.

${ }_{13}$ Por. wyrok w sprawie C-524/04 Test Claimants in Thin Cap Group Litigation, pkt 81, w którym TS sformułował wytyczne, w oparciu o które można uznać umowę pożyczki za transakcję o wyłącznie sztucznym charakterze, zawartą w celu uniknięcia opodatkowania; zob. S. van Thiel, Justifications in Community Law for Income Tax Restrictions on Free Movement: Acte Clair Rules That Can Be Readily Applied by National Courts - Part 1, „European Taxation” 2008, no. 6, s. 279 i n.

${ }^{14}$ T. O'Shea, New Analysis: ECJ Overturns Belgian Thin Cap Rules, „Tax Notes International" 2008 , no. 3 , s. 837 i n. 
TS UE nie ma wątpliwości, że przepisy ograniczające niedostateczną kapitalizację mogą stanowić instrument służący zwalczaniu unikania opodatkowania, jeżeli restrykcjom z nich wynikającym podlegają wyłącznie transakcje w całości lub w części sztuczne, które są podyktowane wyłącznie motywami podatkowymi (minimalizacją lub całkowitą eliminacją obciążenia podatkowego). Nie mogą one jednak wychodzić poza zakres tego, co jest niezbędne, by zapobiegać zjawiskom erozji podstawy opodatkowania w państwie źródła dochodu generowanego w wyniku takiej transakcji. Jeżeli restrykcje wynikające z przepisów, takich jak ograniczające niedostateczną kapitalizację, dotykają każdej transakcji, w której uczestniczą jako jedna ze stron spółki dominujące, rezydenci innego państwa członkowskiego niemalże automatycznie, bez względu na ocenę warunków, na jakich dochodzi do jej zawarcia, stanowią one nieusprawiedliwione ograniczenie swobody przedsiębiorczości, o której mowa w art. 43 TWE (obecnie art. 49 TFUE) w związku z art. 48 TWE (obecnie art. 56 TFUE).

Krajowe regulacje, dotyczące cen transferowych i przedsiębiorstw powiązanych, niezwiązane z problematyką nadmiernego wykorzystywania przez podmioty powiązane zwrotnej metody dokapitalizowania spółek zależnych, były przedmiotem oceny TS UE w kontekście zgodności z gwarantowanymi przez prawo pierwotne fundamentalnymi swobodami traktatowymi w wyroku z dnia 21 stycznia 2010 r. w sprawie C-311/08 Societé de Gestion Industrelle SA (SGI) przeciwko Królestwu Belgii. Sprawa C-311/08 Societé de Gestion Industrelle SA (SGI) odnosiła się do belgijskich przepisów dotyczących opodatkowania nadzwyczajnych lub nieodpłatnych świadczeń (korzyści) uzyskanych od podmiotu powiązanego rezydenta innego państwa członkowskiego UE. Societé de Gestion Industrelle SA, spółka będąca rezydentem Belgii, udzieliła nieoprocentowanej pożyczki spółce zależnej z siedzibą we Francji. W przedmiotowym stanie faktycznym brak było ekonomicznego uzasadnienia dla zawarcia między podmiotami powiązanymi transakcji na tak uzgodnionych warunkach (nieoprocentowana pożyczka), gdyż spółka pożyczkodawca (Societé de Gestion Industrelle SA) znajdowała się w trudnej finansowo sytuacji (strata), zaś francuska spółka zależna wykazała w latach 2001 i 2002 dochód do opodatkowania. Obowiązujące w tym czasie w Belgii regulacje, dotyczące wyceny transferu między podmiotami powiązanymi, różnicowały prawnopodatkową sytuację rezydentów i nierezydentów w kwestii opodatkowania nadzwyczajnych lub nieodpłatnych korzyści uzyskiwanych w wyniku transakcji zawieranych między podmiotami powiązanymi. Nadzwyczajna lub nieodpłatna korzyść udzielana przez rezydenta Belgii rezydentowi innego państwa członkowskiego UE podlegała opodatkowaniu na poziomie podmiotu powiązanego udzielającego takiej korzyści, zaś w przypadkach porównywalnych transakcji, w których uczestniczyli wyłącznie rezydenci Belgii, korzyść taka była opodatkowana na poziomie podmiotu powiązanego - beneficjenta świadczenia. Na tej podstawie belgijskie organy podatkowe dokonały korekty dochodu Societé de Gestion Industrelle SA za lata 2001 i 2002 z tytułu hipotetycznych odsetek od nieoprocentowanej pożyczki udzielonej francuskiej spółce zależnej, 
obliczonych według rynkowej stawki rocznej w wysokości 5\% kwoty brutto. Dodatkowo, odmówiły odliczenia jako kosztów uzyskania przychodu części wydatków poniesionych przez Societé de Gestion Industrelle SA z tytułu wykonywania funkcji zarządczych we francuskiej spółce zależnej, biorąc za podstawę fakt, iż rezygnacja z oprocentowania w umowie pożyczki w sytuacji finansowej, w jakiej znajdowała się Societé de Gestion Industrelle SA, odbiega od warunków, na jakie w porównywalnych transakcjach zgodziłyby się podmioty niepowiązane.

TS UE uznał belgijskie przepisy w tym zakresie za ograniczające gwarantowaną przez prawo pierwotne swobodę przedsiębiorczości (art. 43 TWE, obecnie art. 49 TFUE), gdyż wynikał z nich mniej korzystny podatkowo reżim opodatkowania stosowany wyłącznie do transakcji, w których uczestniczą podmioty powiązane, rezydenci innego państwa członkowskiego UE. Korekta dochodów (zysków) jednego z podmiotów powiązanych rodzi ryzyko ich podwójnego opodatkowania w sensie ekonomicznym. Hipotetyczne odsetki - jako nieodpłatne świadczenie - mogły podlegać opodatkowaniu także w państwie rezydencji beneficjenta, zatem wynikający z prawa belgijskiego reżim korekty dochodów (zysków) podmiotów powiązanych, nakazujący opodatkowanie wartości nieodpłatnych świadczeń na poziomie podmiotu udzielającego, mógł bezpośrednio wpływać na decyzje rezydentów Belgii w przedmiocie inwestowania w kapitał zakładowy spółek rezydentów innych państw członkowskich UE. Mógł także zniechęcać rezydentów innych państw członkowskich UE do tworzenia, nabywania udziałów w spółkach zależnych z siedzibą w Belgii.

TS UE odrzucił argument belgijskich władz podatkowych, które twierdziły, że ryzyko ekonomicznego podwójnego opodatkowania ,hipotetycznych” odsetek od nieodpłatnej pożyczki udzielonej przez Societé de Gestion Industrelle SA francuskiej spółce zależnej nie wynikało wprost z zastosowania belgijskich przepisów, ale z odmowy dokonania korekty odpowiadającej (ang. corresponding adjustment) w drugim państwie członkowskim UE. Ryzyko ekonomicznego podwójnego opodatkowania ,hipotetycznych” odsetek mogło być wyeliminowane poprzez zastosowanie mechanizmów przewidzianych przez Konwencję Arbitrażową, której stronami są zarówno Belgia, jak i Francja. TS UE zauważył jednak, że procedury eliminacji ekonomicznego podwójnego opodatkowania regulowane w Konwencji Arbitrażowej są czasochłonne i do momentu ich zakończenia podatnik musi ponosić ciężar ekonomicznego podwójnego opodatkowania, co może ograniczać mu korzystanie z gwarantowanej przez prawo pierwotne swobody przedsiębiorczości.

W ocenie TS UE belgijski reżim prawny stanowił jednakże usprawiedliwione ograniczenie swobody przedsiębiorczości potrzebą ochrony nadrzędnego interesu publicznego, o ile służy to zabezpieczeniu zrównoważonego podziału kompetencji podatkowych między państwa członkowskie UE w umowach dwustronnych, służących eliminacji podwójnego opodatkowania oraz ma zapobiegać ryzyku unikania/uchylania się od opodatkowania. Zrównoważony podział kom- 
petencji podatkowych (zrównoważona alokacja elementów władztwa podatkowego ${ }^{15}$ między państwa członkowskie UE w umowach dwustronnych w sprawie unikania podwójnego opodatkowania oraz zapobieganie unikaniu/uchylaniu się od opodatkowania są akceptowanymi przez TS UE usprawiedliwieniami dla norm podatkowych prawa krajowego, ograniczających korzystanie przez podatników $\mathrm{z}$ gwarantowanych przez TFUE fundamentalnych swobód traktatowych ${ }^{16}$. TS UE zauważył, że belgijskie przepisy ograniczające rezydentom Belgii „przerzucenie” dochodu w postaci nadzwyczajnego lub nieodpłatnego świadczenia na podmiot powiązany - rezydenta innego państwa członkowskiego UE, zapobiegają zachwianiu równowagi w alokacji prawa do opodatkowania dochodów (majątku) wynegocjowanego $\mathrm{w}$ dwustronnej umowie $\mathrm{w}$ sprawie unikania podwójnego opodatkowania zawartej między Belgią a drugim umawiającym się państwem, gdyż de facto pozwalają Belgii na opodatkowanie dochodu (zysku), jaki osiągnięty zostałby, gdyby transakcja zawarta przez podmioty powiązane została dokonana na warunkach respektujących zasadę długości ramienia.

Ponadto, zdaniem TS UE obowiązujące w Belgii przepisy w zakresie korekty dochodów (zysków) generowanych przez podmioty powiązane w wyniku nadzwyczajnych lub nieodpłatnych transakcji, umożliwiające ich opodatkowanie w Belgii na poziomie podmiotu udzielającego nieodpłatnego świadczenia, mają wyraźnie na celu zapobieganie unikaniu opodatkowania. Wyeliminowanie wynikającego z prawa belgijskiego mechanizmu korekty podatkowo-prawnych następstw takich transakcji oznaczałoby zgodę Belgii na przerzucanie dochodów (zysków), jakich należałoby oczekiwać, gdyby transakcja zawarta między podmiotami powiązanymi respektowała w pełni zasadę długości ramienia, przy wykorzystaniu przez podmioty powiązane w całości sztucznych z ekonomicznego

${ }^{15}$ Koncepcja zrównoważonego podziału kompetencji podatkowych między państwa członkowskie UE w umowie dwustronnej służącej unikaniu podwójnego opodatkowania została powołana po raz pierwszy dla usprawiedliwienia restrykcyjnego względem fundamentalnych swobód traktatowych wewnętrznych uregulowań podatkowych w państwie członkowskim UE w wyroku TS UE z dnia 13 grudnia 2005 r. w sprawie C-446/03 Marks \& Spencer [2005] ECR I-10837; TS UE uznał wówczas, że ograniczenie przez prawo krajowe państwa członkowskiego fundamentalnych swobód traktatowych jest usprawiedliwione, jeżeli służy łącznie zapewnieniu równowagi w podziale prawa do opodatkowania poszczególnych kategorii dochodu lub majątku w wynegocjowanej dwustronnej umowie w sprawie unikania podwójnego opodatkowania (tj. gwarantuje państwu członkowskiemu wykonywanie jego władztwa podatkowego w takim zakresie, w jakim wynika ono z prawa wewnętrznego tego państwa oraz z postanowień dwustronnej umowy zawartej z drugim umawiającym się państwem), eliminuje zagrożenie dwukrotnego rozliczenia strat oraz zapobiega ryzyku unikania przez podatników opodatkowania lub uchylania się od opodatkowania, zob. ECJ Direct Tax Compass 2011, s. 104-105.

${ }^{16}$ I. Angelova, Justifications for Restricting Fundamental Freedoms Accepted by the European Court of Justice, „The EC Tax Journal” 2011-2012, vol. 12, s. 99-116, por. L. Hinnekens, Basis and scope of public interest justification of national tax measures infringing fundamental Treaty Freedoms, [w:] The EU Freedoms and Taxation, red. F. Vanistendael, EATLP International Tax Series, vol. 2, IBFD, Amsterdam 2006, s. 73 i n. 
punktu widzenia transakcji i lokowaniu dochodów (zysków) z nich wynikających w innych jurysdykcjach podatkowych, gdzie przykładowo obowiązują niższe stawki podatkowe lub dochody z tego tytułu podlegają zwolnieniu z podatku.

W ocenie TS UE belgijskie przepisy przewidujące korektę dochodów (zysków) podmiotów powiązanych z tytułu nadzwyczajnych lub nieodpłatnych świadczeń (korzyści) stanowiły proporcjonalny i obiektywny środek służący zapobieganiu unikania opodatkowania. Podatnik, Societé de Gestion Industrelle SA, miał możliwość - bez przeszkód natury administracyjno-prawnej - przedstawienia organom podatkowym dowodów, wskazujących gospodarcze uzasadnienie zawarcia nieoprocentowanej umowy pożyczki z francuską spółką zależną. Ponadto, korekta dokonana przez belgijskie organy podatkowe, polegająca na podwyższeniu podstawy opodatkowania Societé de Gestion Industrelle SA o kwotę hipotetycznych odsetek, została dokonana z zachowaniem zasady długości ramienia, tj. hipotetyczne odsetki zostały ustalone przez organ podatkowy w kwocie odpowiadającej wysokości oprocentowania stosowanego w porównywalnych transakcjach zawieranych przez podmioty niepowiązane.

Reasumując, zaprezentowana linia orzecznicza TS UE akcentuje cel przepisów ograniczających niedostateczną kapitalizację oraz innych unormowań opartych na zasadzie długości ramienia w kontekście usprawiedliwionego ograniczenia swobody przedsiębiorczości. TS jest przekonany, że każde państwo członkowskie ma prawo przedsięwziąć środki zmierzające do wyeliminowania niekorzystnych z punktu widzenia interesu ogólnego podatkowych następstw w całości sztucznych transakcji, jeżeli zmierzają one wyłącznie do unikania opodatkowania. Zgodzić się należy, że zasada długości ramienia pełni nieocenioną rolę czynnika obiektywizującego ocenę przy określeniu, co jest rzeczywiste i racjonalne, a co sztuczne i wygodne $\mathrm{z}$ podatkowego punktu widzenia. W związku z tym odsetki wypłacane $\mathrm{z}$ tytułu pożyczki zawartej na zasadach odbiegających od zasady długości ramienia to wyzwanie. Jednakże Trybunał jest przekonany, że podatnik może niekiedy odbiec od zasady długości ramienia, jeżeli ma to swoje ekonomiczne usprawiedliwienie.

TS UE ustanowił dwa warunki w celu zapewnienia realizacji postulatu proporcjonalności:

1) podatnik musi mieć możliwość wykazania gospodarczego uzasadnienia dla uzgodnienia (narzucenia) przez podmioty powiązane warunków we wzajemnych transakcjach, które różnią się od warunków rynkowych (nawet jeżeli pożyczka udzielona w sprawie Lankhorst-Hohorst nie przeszłaby testu o zgodność z zasadą długości ramienia, służyła ona jakimś gospodarczym celom - była uzasadniona gospodarczo) oraz

2) nawet w przypadku, gdy w konkluzji należy uznać pożyczkę za sztuczną transakcję (brak gospodarczego uzasadnienia), reakcja prawa podatkowego nie może wychodzić ponad zakres tego, co jest niezbędne do dokonania rekategoryzacji transakcji w sposób odpowiadający temu, co byłoby uzgodnione w niej, gdyby transakcja ta została zawarta na warunkach rynkowych przez podmioty niepowiązane. 